\title{
耳下腺転移をきたした眼瞼アポクリン腺癌例
}

\author{
山田ちえ子・山崎 徳和・平尾 元康 \\ 新谷 朋子・承見 徹夫
}

\section{A Case of Apocrine Carcinoma of the Eyelid with Parotid Gland Lymph Node Metastasis}

\author{
Chieko Yamada, Norikazu Yamazaki, Motoyasu Hirao, \\ Tomoko Shintani and Tetsuo Himi \\ (Sapporo Medical University)
}

\begin{abstract}
Apocrine carcinoma of the eyelid is a rare neoplasm. We present a case of this carcinoma accompanied by parotid gland lymph node metastasis. The primary tumor of the eyelid was resected and diagnosed as an idiopathic poorly differentiated carcinoma of the skin. After postoperative radiotherapy to the eyelid, a small mass was found in the parotid gland and diagnosed as lymph node metastasis of apocrine carcinoma from the eyelid tumor. With apocrine carcinoma, there is a high risk of lymph node metastasis. To treat this metastasis, we administered postoperative radiotherapy to the parotid gland and ipsilateral neck region.
\end{abstract}

Key words : apocrine carcinoma, eyelid, metastatic tumor, parotid gland, regional lymph node

\section{はじめに}

耳下腺には約 $20 \sim 30$ 個のリンパ節と豊富なリンパ網 が存在し，前額部・側頭部・耳前部・眼瞼・煩部などの リンパ液が灌流している，それゆえ頭頸部皮膚悪性腫瘍 の半数以上が耳下腺内リンパ節転移をきたすと考えら れ，時には転移性耳下腺腫瘤が初発症状となることもあ る. 眼瞼脂腺癌などの眼瞼付属腺悪性腫瘍も耳下腺内リ ンパ節転移をきたす腫瘍の一つであり，この眼臉付属腺 由来の腫瘍のなかでも眼臉アポクリン腺癌はきわめてま れな腫瘍である.今回われわれは原発巣治療後に耳下腺 内リンパ節転移をきたし，耳下腺腫瘍摘出にて組織学的 な確定診断が得られた下眼瞼原発アポクリン腺癌症例を 経験したので文献的考察を加え報告する.

\section{症例}

患者 : 77 歳, 男性.

主訴：左耳前部腫瘤.
家族歷：特記すべきことなし．

既往歴：脳梗塞 (73 歳). 前立腺癌 (77 歳).

現病歴：平成 12 年 4 月頃より左下眼瞼に腫瘤が出現 し, 同年 6 月 30 日当院眼科にて腫瘍摘出術施行. 病理組 織診にて低分化型上皮系，皮膚由来の悪性腫瘍と考えら れたが確定診断に至らなかった。 同年 $7 \sim 8$ 月，左下眼 瞼に $6 \mathrm{MeV}$ 電子線照射 $60 \mathrm{~Gy} / 20 \mathrm{fr}$ 施行. 同年 11 月施行 の CT にて左耳下腺内の腫瘤を認め，平成 13 年 1 月 12 日当科紹介となった。

現症：耳鼻咽喉に特記すべき所見なく, 左耳前部に可 動性不良, 弾性硬な直径 $10 \mathrm{~mm}$ の腫瘤を触知した. 顔面 神経麻痺は認めなかった。

検査所見と経過: 穿刺吸引細胞診にて class $\mathrm{V}$ と眼瞼腫 瘍の転移性病変の可能性が強く疑われ，同年 4 月 3 日当 科入院. CT 亿て左耳下腺内に直径約 $10 \mathrm{~mm}$ の均一に造 影される境界明膫な腫瘤を認め（図 1), MRI では $\mathrm{T} 1$, $\mathrm{T} 2$ ともに低信号, ガドリニウムにてよく造影される腫瘤 


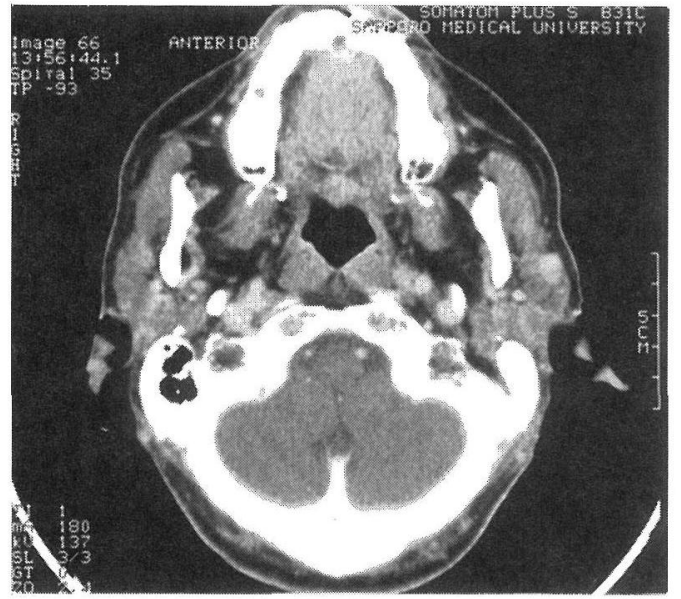

图 1 造影 CT 所見

左耳下腺浅葉に直径約 $10 \mathrm{~mm}$ の均一に造影される境界明 瞭な腫瘤を認める。

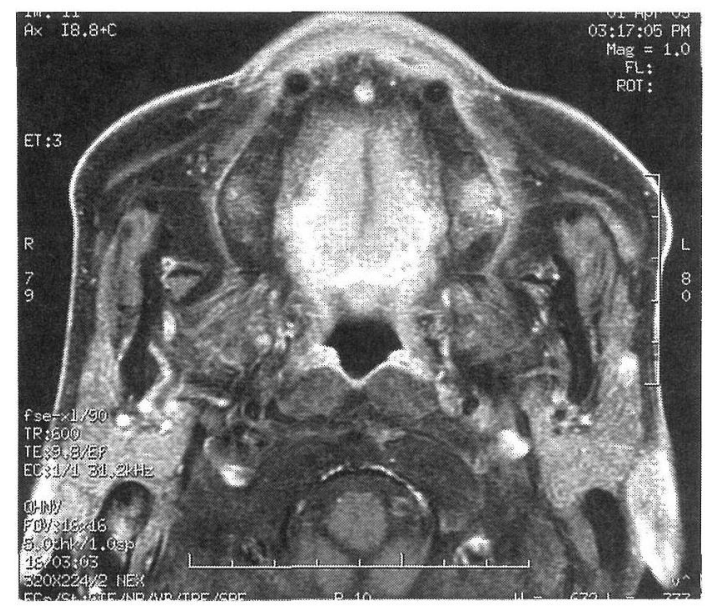

図 2 ガドリニウム造影 MRI 所見

左耳下腺浅葉に直径約 $10 \mathrm{~mm}$ のガドリニウムにてよく造 影される境界明膫な腫瘤を認める。

を認めた（図 2)。同年 4 月 9 日全身麻酔下に左耳下腺部 分切除術施行し, 病理組織診にてアポクリン腺癌の耳下 腺内リンパ節転移と診断された。術後， $4 \mathrm{MV} \mathrm{X}$ 線照射 を左頸部に $50 \mathrm{~Gy} / 25 \mathrm{fr}$ 施行, 左耳下腺部に $10 \mathrm{~Gy} / 5 \mathrm{fr}$ 追 加照射行い，現在再発なく経過観察中である.

病理組織学的所見：HE 染色の弱拡大では耳下腺組織 内に被膜を有するリンパ節を認め，腫愓細胞のシート状 の増殖とその周りにリンパ球浸潤を認めた。強拡大では, 好酸性の豊かな細胞質を持つ低分化な腫瘍細胞の增殖を 認め, 左下眼瞼腫瘍の組織でも同様の所見が認められた

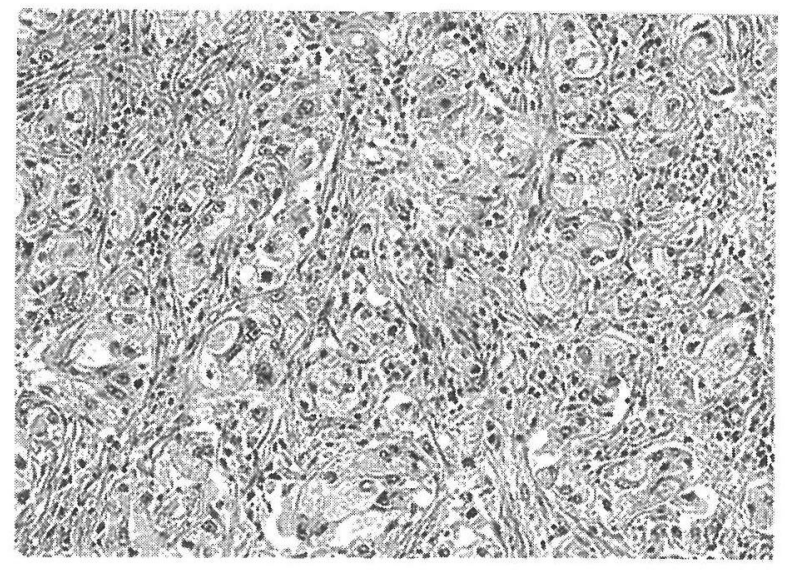

図 3 病理組織学的所見 (耳下腺腫瘍. HE 染色, $\times 400)$ 好酸性の豊かな細胞質を持つ低分化な腫瘍細胞のシート 状の増殖とその周りにリンパ球浸潤を認める.

(図 3). GCDFP15 染色にて腫瘍細胞の細胞質が強く染ま り，これらの所見から，左下眼瞼原発アポクリン腺癌の 耳下腺内リンパ節転移と診断された。

\section{考 察}

皮膚などの付属腺由来悪性腫瘍のうち，アポクリン腺 癌はまれな悪性腫瘍であり, 診断困難なことも多い。 Warke ${ }^{11}$ によれば発症年齢は25 91歳に及び, 平均 57.9 歳 であり 40 歳未満の発症は少ない。好発部位は腋窩が最も 多く, 次いで肛門・外陰部, 外耳道, 眼瞼などであるが, 睫毛に付属するアポクリン腺であるモル腺由来の癌はき わめてまれである。

アポクリン腺癌の診断は病理組織学的所見, 特殊染色 所見によって行われることが多く, Kipkie ら2) は(1)解剖 学的にアポクリン腺が存在する部位に生じていること, (2)腫瘍細胞が強いエオジン好性の胞体を持つこと，(3)断 頭分泌の所見が認められること, (4)鉄染色陽性であるこ とを挙げ, Paties ら ${ }^{3)}$ は(1)断頭分泌所見, (2)細胞内もし くは管腔内のジアスターゼ抵抗性 PAS 陽性物質の存在, (3) GCDFP15 染色陽性であることを挙げている。自験例 では比較的低分化な腫瘍であったため, 明瞭な管腔構造 を認めず，断頭分泌も明らかではなかったが，エオジン 好性の腫瘍細胞の增殖を認め GCDFP15 染色陽性であっ たことより，アポクリン腺癌と診断した。

アポクリン腺癌は所属リンパ節転移や遠隔転移を生じ らると考えられ1)，Dhawan ら4) によればアポクリン腺癌 33 例中半数以上がリンパ節転移を生じ, 10 例が内臟転移 
を生じて死亡したとし, Warkel ${ }^{11}$ は 23 例中 9 例, 約 40\% が腫瘍死に至ったと報告している．自験例でも眼瞼悪性 腫瘍治療の約 5 カ月後に所属リンパ節である耳下腺内リ ンパ節へ転移が明らかとなり, 耳前部腫瘤は転移性耳下 腺腫瘍と診断された。

転移性耳下腺腫瘍は耳下腺リンパ節転移（耳下腺周囲 リンパ節，耳下腺内リンパ節）と耳下腺実質への血行性 転移に分けられ ${ }^{5)}$, Conley ら ${ }^{6)}$ は転移性耳下腺腫瘍 81 例 について, 耳下腺周囲リンパ節 33 例 (40.7\%), 耳下腺 内リンパ節 29 例 $(35.8 \%)$, 耳下腺案質への浸潤・転移 19 例 (23.5\%) であったと報告している. また Seifert ら7) は転移性耳下腺腫瘍 75 例中 38 例が耳下腺リンパ節転移 であり, 37例が耳下腺実質転移であったと報告している。

また耳下腺腫瘍における転移性腫瘍の割合は比較的少 なく, Jecker ら ${ }^{8)}$ は耳下腺手術を行った 347 例中 $27 \%$ が 悪性で 6\% (21 例) が転移であったと報告している. 本 邦の耳下腺腫瘍における転移性腫瘍の割合は村上ら9) が 25 例中 5 例, 加納ら ${ }^{10)}$ が 30 例中 1 例，金子ら ${ }^{11)}$ が 44 例中 1 例であったとしている.

転移性耳下腺腫湯の原発部位については自験例のごと く頭頸部悪性腫瘍, 特に皮虐悪性腫瘍が多い. Seifert ら 7 ) によると転移性耳下腺腫崵 75 例のうち 49 例は頭頸部領 域からの転移であり,その組織型は 23 例が扁平上皮癌で 15 例が悪性黒色腫であった。 また，耳下腺実質への転移 は肺癌 5 例, 腎癌 4 例, 乳癌 2 例と遠隔転移を多く認め ていた。

転移性耳下腺腫瘍の治療は原発部位やその組織型に よって異なるが，一般的に外科的切除が行われることが 多く, 術前・術後放射線療法や化学療法を併用すること むある. 手術についてはその切除範囲, 顔面神経の処理, 頸部郭清併用の有無などが問題となる.

切除範囲に関して Storm $ら^{12)}$ は眼瞼・前頭部・側頭 部・煩部後方・耳後部など頭部顔面皮膚悪性腫瘍の場合, 原発巣の広範囲切除と耳下腺浅葉切除ならびに頸部郭清 を施行すべきであると述べている．しかし今回のように 眼瞼腫瘍の場合, 整容的な面から広範囲切除に同意を得 ることは難しく，放射線治療を併用することがあり，わ れわれの症例も眼瞼の原発巣に関しては腫瘍摘出術後に 電子線照射を併用した。

また, 耳下腺の切除範囲については浅葉摘出か全摘か, また顔面神経を温存するか否かについてが重要な問題で あるが，Jecker ら ${ }^{8)}$ は全摘は生存率の向上を得られない
だけでなく，患者の QOL を低下させるため避けるべき であり，放射線治療や化学療法を併用し，できるだけ顔 面神経を温存するべきであると述べている，頸部郭清に ついて Jackson ら ${ }^{13)}$ は臨床的には陰性で頸部郭清を行っ た症例の $24 \%$ で頸部リンパ節転移を認めたことから，皮 膚癌の耳下腺摘出術を行う時には頸部郭清も加えるべき だと述べている，われわれの症例では，まず原発巣の病 理学的診断が確定しておらず，診断的意味も含めて耳下 腺部分切除術を行い，その結果から眼臉アポクリン腺癌 の耳下腺内リンパ節転移と診断されたため，耳下腺部に 加え予防的に顓部にも放射線治療を行った。

耳下腺リンパ節転移の放射線治療について delCharco $ら^{14)}$ は術前放射線治療十手術の 5 年間の局所制御率を 80 $\%$, 手術十術後放射線治療では $90 \%$, 放射線治療単独で は $53 \%$ であったと報告している，放射線治療の併用に よって切除不可能の症例の腫瘍の減量を行ったり, 手術 不可能な症例の局所制御が可能であったり，顔面神経の 温存を図れるといった利点があるため, 放射線治療は耳 下腺リンパ節転移に対しても検討されるべき治療である と考える.

転移性耳下腺腫瘍は耳下腺腫瘍のなかでは比較的まれ であるが，そのほとんどが頭部顔面皮膚悪性腫瘍からの 転移であり，近年の皮膚悪性腫瘍の増加によって耳鼻咽 喉科医が遭遇する機会も増加すると予想される8). また， 頭部顔面皮膚悪性腫瘍の初発症状が耳下腺リンパ節腫脹 であった症例も報告されていることから 7)8131141)，耳下腺 腫瘍を診察する際には，転移性耳下腺腫瘍も鑑別診断と して念頭に置き，既往歴についての十分な問診，頭部お よび顔面皮膚の詳細な観察も重要であると考えられた。

\section{まとめ}

耳下腺内リンパ節転移をきたした，まれな下眼臉原発 アポクリン腺癌症例を報告した。原発巣, 転移巣ともに 手術的切除および放射線治療を行った．自験例をもとに アポクリン腺癌, 転移性耳下腺腫瘍につき文献的考察を 行った。

\section{参考文献}

1) Warkel RL : Selected apocrine neoplasms. J Cutan Pathol 11 : $437 \sim 449,1984$.

2) Kipkie G and Haust MD : Carcinoma of apocrine glands. Arch Dermatol $78: 440,1958$. 
3) Paties C, Taccagni GL, Papotti M, et al. : Apocrine carcinoma of the skin; a clinicopathologic, immunocytochemical, and ultrastructural study. Cancer $71: 375 \sim 381,1993$.

4) Dhawan SS, Nanda VS, Grekin S, et al. : Apocrine adenocarcinoma; case report and review of the literature. J Dermatol Surg Oncol $16: 468 \sim 470,1990$.

5）今井佑二, 原 浩貴, 相良 健, 他 : 耳下腺リンパ節にみ られた転移性腫瘍の 2 例，耳鼻臨床 $87: 783 \sim 787,1994$.

6) Conley J and Arena S : Parotid gland as a focus of metastasis. Arch Surg $87: 757 \sim 764,1963$

7) Seifert G, Hennings $K$ and Caselitz $J$ : Metastatic tumors to the parotid and submandibular glands; analysis and differential diagnosis of 108 cases. Pathol Res Pract 181:684 692, 1986.

8) Jecker P and Hartwein J : Metastasis to the parptid gland; is a radical surgical approach justified? Am J Otolaryngol 17:102 $105,1996$.

9）村上 泰, 猪 忠彦, 堀内政敏, 他 : 耳下腺腫瘍 70 症例の 治療体験. 耳喉 $48: 53 \sim 66,1976$.
10）加納直行, 牧本一男, 藤村英一, 他：過去 10 年間における 耳下腺腫瘍の統計. 耳鼻臨床 $75: 1657 \sim 1666,1982$.

11）金子まどか, 柊 光一, 古川政樹, 他：耳下腺腫瘍の統計 的観察. 耳鼻 $33: 261 \sim 268,1987$.

12) Storm FK, Eilber FR, Sparks FC, et al. : A prospective study of parotid metastasis from head and neck cancer. Am J Surg 134: $115 \sim 119,1977$.

13) Jackson GL and Ballantyne AJ : Role of parotidectomy for skin cancer of the head and neck. Am J Surg 142:464 469, 1981.

14) delCharco JO, Mendenhall WM, Parsons JT, et al. : Carcinoma of the skin metastatic to the parotid area lymph nodes. Head Neck $20: 369 \sim 373,1998$.

原稿受付：平成14年 1 月 18 日

原稿採択：平成14年 3 月 6 日

別刷請求先 : 山田ちえ子

厂060-8543 札幌市中央区南1条西16丁目

札幌医科大学医学部耳鼻咽喉科学教室 